\title{
ANALISIS PENETAPAN HARGA POKOK PRODUK BERSAMA PADA PT SULINDAFIN
}

\author{
Eko Narto \\ Dosen Fakultas Ekonomi dan Bisnis Universitas Muhammadiyah Tangerang \\ Mochammad Sadam Husein \\ Alumni Fakultas Ekonomi dan Bisnis Universitas Muhammadiyah Tangerang
}

\begin{abstract}
A company that produces more than one type of goods is necessary to calculate the cost of a joint product used to allocate each type of product produced with the purpose of financial reporting as well as the basis for the sale price of each type of goods. The purpose of this paper is to: To know the allocation of product costs together calculation of profit and loss segment of the product together with variable costing method at PT Sulindafin.

Based on the results of the discussion and analysis of the costing of joint product prices, the allocation of joint cost to PT Sulindafin using the market value method and the calculation of profit and loss segment of the joint product at PT Sulindafin using variable costing method.
\end{abstract}

Keywords: Joint Cost, Market Value Method, Variable Costing Method

\begin{abstract}
Abstrak
suatu perusaahan yang memproduksi lebih dari satu jenis barang sangat diperlukan perhitungan biaya produk bersama yang digunakan untuk mengalokasikan tiap-tiap jenis produk yang dihasilkan dengan tujuan pelaporan keuangan serta menjadi dasar untuk harga jual tiap-tiap jenis barang tersebut. Tujuan penulisan ini adalah untuk : Untuk mengetahui alokasi biaya produk bersama perhitungan laba rugi segmen atas produk bersama dengan metode variable costing pada PT Sulindafin.
\end{abstract}


Berdasarkan hasil pembahasan dan analisis penetapan harga pokok produk bersama, alokasi biaya bersama pada PT Sulindafin menggunakan metode nilai pasar dan perhitungan laba rugi segmen atas produk bersama pada PT Sulindafin menggunakan metode variable costing.

Kata kunci : Alokasi Biaya Bersama, Metode Nilai Pasar, Metode Variable Costing

\section{PENDAHULUAN}

\section{Latar Belakang Masalah}

Sebuah perusahaan yang bergerak dibidang manufaktur, manajer akan dihadapkan dengan dua pilihan yang cukup krusial dalam memutuskan kegiatan produksinya. Pilihan yang dimaksud tersebut yaitu pilihan untuk memproduksi barang sendiri atau membeli barang dari perusahaan lain. Pengambilan keputusan yang tepat harus dievaluasi dengan baik yaitu jika memproduksi sendiri maka biaya yang timbul hanya biaya variable namun jika membeli dari perusahaan lain maka biaya transportasi atau biaya-biaya yang timbul untuk menyampaikan produk yang dibeli ke perusahaan. Komarudin Ahmad ( 2013 : 133)

Pilihan yang kurang tepat akan mengakibatkan kerugian bagi perusahaan itu sendiri. Sebagai seorang manajer haruslah cermat dalam membaca situsi tersebut. Sebelum keputusan yang akan diambil manajer harus menghitung biaya-biaya yang akan dikeluarkan oleh perusahaan. Biaya-biaya tersebut akan dihitung dalam perhitungan harga pokok produksi.

Setelah dihitung secara tepat biaya-biaya yang harus dikeluarkan oleh perusahaan maka akan keluar perbandingan biaya antara memproduksi barang sendiri atau membeli dari perusahaan lain. Pada akhirnya akan terlihat biaya mana yang lebih kecil untuk diambil keputusannya. Faktor-faktor yang juga diperhitungkan sebelum manajer mengambil keputusan yaitu menjaga kerahasian produk perusaahan, mampu 
atau tidaknya perusahaan memproduksi bagian tertentu dari barang yang akan diproduksi dan penyempurnaan hasil produksi”. Hery ( $2016: 136$ )

\section{LANDASAN TEORI}

\section{Analisis Perilaku Biaya}

Menurut Kautsar Riza Salman dan Moch. Farid (2016:42) Perilaku biaya adalah cara biaya berubah dalam hubungannya dengan perubahan penggunaan aktivitas atau untuk mengambarkan apakah biaya berubah seiring dengan perubahan output.

Berdasarkan perilakunya, biaya terbagi menjadi tiga bagian yaitu biaya tetap, biaya variabel dan biaya campuran.

\section{Biaya Tetap (Fixed Cost)}

Menurut Iskandar putong (2013:215) adalah Biaya tetap merupakan biaya yang dikeluarkan oleh perusahan dengan tidak memandang apakah perusahaan itu sedang menghasilkan barang atau tidak, seperti gaji karyawan, abodemen, sewa dan lain-lain.

2. Biaya Variabel (Variable Cost)

Biaya variabel adalah biaya yang besaranya tergantung pada tingkat produksi dan penggunaan bahan baku. Contoh biaya variable antara lain upah lembur, biaya komunikasi biaya pengiriman dan lain-lain.

\section{Biaya Total (Total Cost)}

Biaya total merupakan penjumlahan semua jenis biaya yang ada (biaya tetap dan biaya variabel). Suherman Rosyidi (2014:372)

\section{Klasifikasi Biaya}

Berikut adalah beberapa macam biaya yang dilihat dari beberapa sudut pandang. 
1. Biaya Berdasarkan Produksi

Dalam hal biaya berdasarkan produksi ini dapat terbagi menjadi dua bagian yang dipisahkan antara lain biaya produksi dan biaya non produksi.
a. Biaya Produksi
b. Biaya Non Produksi

2. Biaya Berdasarkan Obyek Biaya

Dalam hal biaya berdasarkan obyek biaya ini terbagi menjadi dua bagian, yaitu biaya langsung dan biaya tidak langsung.
a. Biaya Langsung
b. Biaya Tidak Langsung

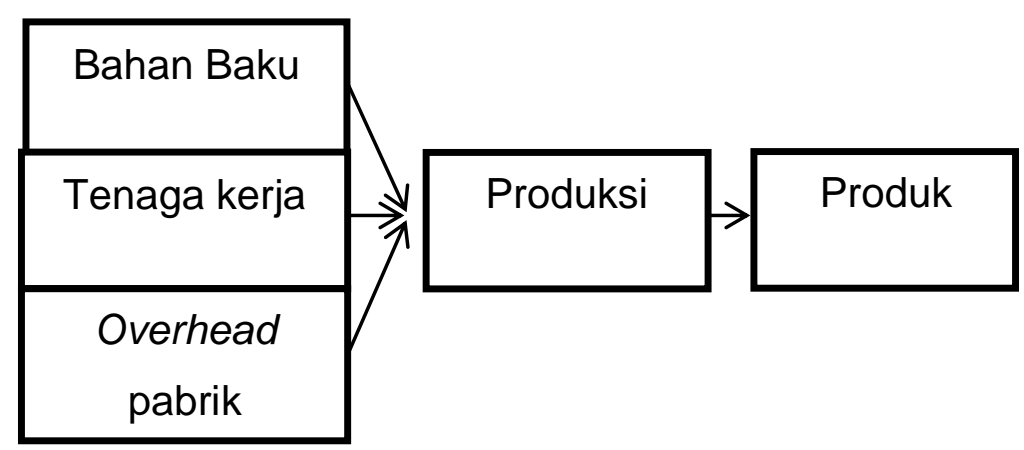

Gambar 2.1 Proses menghasilkan produk Sumber: Bastian Bustami dan Nurlela (2013:2)

\section{Metode Pengumpulan Harga Pokok Produksi}

\section{Metode Harga Pokok Pesanan (Job Costing Method)}

Menurut Hery (2015:582) adalah Metode harga pokok pesanan merupakan metode yang digunakan untuk menetapkan biaya atas produk atau jasa yang berbeda serta metode ini tepat untuk perusahaan dengan produk atau jasa layanan yang beragam.

\section{Metode Harga Pokok Proses (Job Costing Method)}


Menurut Hery (2015:582) adalah Metode harga pokok proses merupakan metode yang digunakan untuk menetapkan biaya atas produk yang identik atau serupa serta metode ini besarnya biaya untuk satu unit produk akan sama dengan besarnya biaya untuk setiap unit produk lainnya.

\section{Metode Penghitungan Harga Pokok Produksi}

1. Metode Produksi Penuh (Full Costing)

Metode penuh produksi (full costing) adalah metode yang penentuan biaya produksi dari seluruh biaya baik yang bersifat tetap maupun bersifat variabel. Handri Kusuma, Zulkifli dan Sulastiningsih (2013:136).

2. Metode Variabel Produksi (Variable Costing)

Metode variable produksi (variable costing)adalah metode yang penentuan biaya produksi dari biaya variabel saja yang dibebankan. Handri Kusuma, Zulkifli dan Sulastiningsih (2013:135).

\section{Harga Pokok Produk Bersama}

a. Metode Harga Pasar (Nilai Jual)

Metode ini merupakan pembebanan biaya bersama atas dasar nilai jual masingmasing produk. Bastian Bustami, Nurlela (2013:158)

1) Harga jual diketahui pada saat titik pisah

Rumus :

$\begin{array}{ccc}\text { Pembebanan } & \begin{array}{c}\text { Jumlah nilai jual } \\ \text { masing-masing produk } \\ \text { Bersama }\end{array} & \begin{array}{c}\text { Biaya } \\ \text { Jumlah nilai jual } \\ \text { Keseluruhan produk }\end{array} \\ & \text { Bersama }\end{array}$

2) Harga jual tidak diketahui pada saat titik pisah

Rumus : 


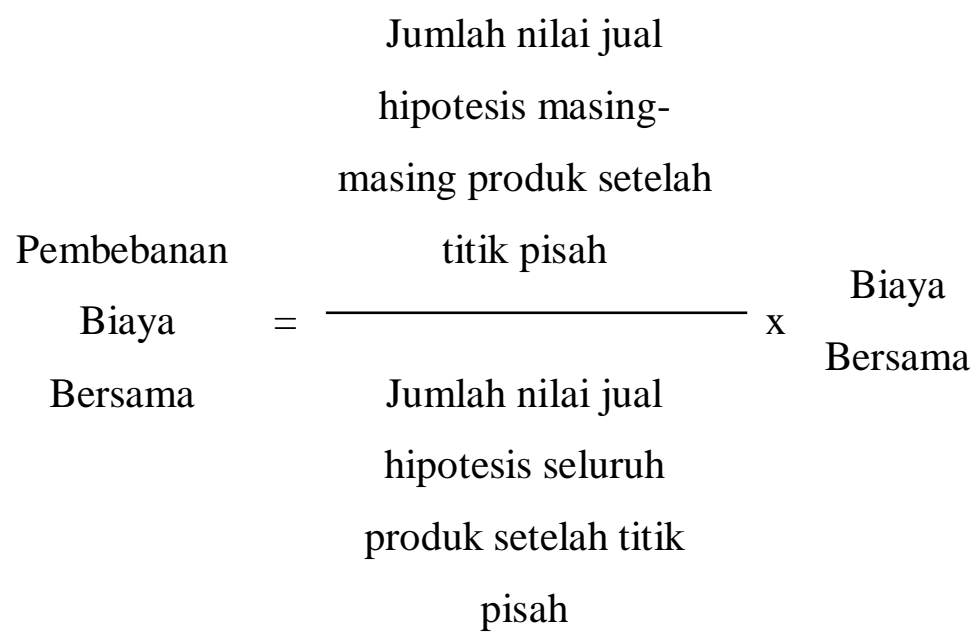

b. Metode Unit Fisik

Rumus :

Jumlah unit masing-masing

Pembebana

produk

n biaya

$=$

bersama

Jumlah unit keseluruha

Biaya

Bersama

produk

c. Metode Rata-rata per unit

Rumus:

Pembebanan
biaya bersama $\quad$ Biaya per unit $\quad x \quad \begin{gathered}\text { Jumlah unit } \\ \text { masing-masing } \\ \text { produk }\end{gathered}$

d. Metode Rata-Rata Tertimbang

Rumus:

$\begin{aligned} & \text { Pembebanan } \\ & \text { biaya }\end{aligned}=\frac{\begin{array}{c}\text { Jumlah penimbang rata- } \\ \text { rata setiap produk }\end{array}}{\begin{array}{c}\text { Jumlah penimbang rata- } \\ \text { rata seluruh produk }\end{array}} \quad \begin{gathered}\text { Biaya } \\ \text { bersama }\end{gathered}$




\section{Metodologi Penulisan}

\section{Pendekatan Penelitian}

Jenis penelitian yang digunakan adalah studi lapangan yaitu penelitian yang dilakukan secara langsung pada perusahaan yang bersangkutan untuk memperoleh data sekunder dan informasi yang dibutuhkan. Teknik pengumpulan data dilakukan dengan observasi yaitu mengadakan kegiatan pengamatan langsung terhadap objek penelitian untuk lebih memahami kondisi perusahaan. Dan juga menggunakan studi pustaka yaitu mencari dan mengumpulkan bahan yang berhubungan dengan masalah yang diteliti dengan cara membaca, mempelajari, dan mendalami literatur-literatur maupun referensi yang berhubungan dengan masalah yang dibahas dalam penelitian ini.

\section{Objek dan Subjek Penelitian}

Objek dalam penelitian ini adalah harga pokok produk bersama, dan subjek penelitian PT Sulindafin yang merupakan salah satu industri swasta yang bergerak dibidang produksi benang, kapas dan fiber chip.

\section{Jenis Data}

Metode pengumpulan data yang digunakan adalah dengan menggunakan metode penelitian kepustakaan yaitu dengan mengacu kepada buku-buku yang berkaitan dengan penelitian serta sumber data yang berasal dari dokumen (data sekunder).

\section{Teknik Pengumpulan Data}

Teknik pengumpulan data yang digunakan dalam penelitian adalah sebagai berikut : Penelitian Lapangan (Field Research) merupakan teknik pengumpulan data yang dilakukan dengan cara terjun langsung pada objek penelitian untuk mendapatkan data yang diperlukan yang meliputi wawancara dan observasi. Penelitian Kepustakaan (Library Research) peneliti memperoleh dari literature, buku-buku referensi yang 
berhubungan dengan dengan masalah untuk memperoleh data sekunder sebagai landasan teori.

\section{Hasil Penelitian dan Pembahasan}

Hasil Produksi Produk Bersama

\begin{tabular}{|c|l|c|r|}
\hline No & \multicolumn{1}{|c|}{ Nama Produk } & Satuan & Jumlah Produksi \\
\hline 1 & Full Oriented Yarn (FOY) & $\mathrm{Kg}$ & $1.812 .392,51$ \\
\hline 2 & Draw Twister Yarn (DTY) & $\mathrm{Kg}$ & $1.396 .174,93$ \\
\hline 3 & Staple Fiber (FSP) & $\mathrm{Kg}$ & $892.401,37$ \\
\hline 4 & Chip Polyester & $\mathrm{Kg}$ & $333.534,20$ \\
\hline \multicolumn{2}{|c|}{ Total } & $\mathrm{Kg}$ & $4.434 .028,00$ \\
\hline
\end{tabular}

Tabel: 4.2 Hasil produksi utama bulan April 2016

Sumber: Dept. Accounting PT Sulindafin

\begin{tabular}{|c|l|c|r|}
\hline No & \multicolumn{1}{|c|}{ Nama Produk } & Satuan & Jumlah Produksi \\
\hline 1 & Bihun & $\mathrm{Kg}$ & $23.562,40$ \\
\hline 2 & Crimped & $\mathrm{Kg}$ & $15.132,87$ \\
\hline 3 & Tow & $\mathrm{Kg}$ & $10.554,12$ \\
\hline 4 & Cake Monomer & $\mathrm{Kg}$ & $5.779,98$ \\
\hline & Total & $\mathrm{Kg}$ & $55.029,37$ \\
\hline
\end{tabular}

Tabel: 4.3 Hasil produksi sampingan bulan April 2016

Sumber: Dept. Accounting PT Sulindafin 
Penjelasan lebih lanjut tentang hasil produksi PT Sulindafin adalah sebagai berikut:

\section{Full Oriented Yarn (FOY)}

Produk ini merupakan benang yang memiliki sifat tekstur benang yang sangat kuat dan kemulurannya sangat rendah dikarenakanmengalami proses perenggangan dengan tegangan yang sangat tinggi serta ditambah dengan pemanasan yang tinggi pula yang mengakibatkan terjadinya reorientasi molekul serat sehingga derajat orientasinya menjadi sangat tinggi.

2. Draw Textured Yarn (DTY)

Produk ini merupakan benang yang memiliki sifat tektur keriting yang memungkinkan mudah terbawa oleh semburan angin sehingga pemakaian angin lebih hemat dibanding benang yang tidak bertekstur /flat fillament yang pada umumnya dipakai untuk pakan / filling yarn.

3. Polyester Staple Fiber (PSF)

Produk ini merupakan serat sintetis dengan ukuran tertentu menyerupai kapas dan memiliki sifat mudah meleleh dijadikan sebagai campuran dengan produk lain untuk modifikasi polyest

4. Chip Polyester

Produk ini merupakan bijih plastik kering yang dijadikan bahan dalam pembuatan benang polyester.

5. Bihun

Produk ini merupakan produk yang tidak berhasil sempurna menjadi FOY dikarenakan kekurangan tingkat pemanasan saat proses berlangsung.

6. Crimped

Produk ini merupakan produk yang tidak berhasil sempurna manjadi DTY dikarenakan suplay bahan baku tersendat saat proses berlangsung. 
7. Tow

Produk ini merupakan produk yang tidak berhasil sempurna menjadi Staple Fiber dikarenakan mesin pengaduk campuran bahan tidak bekerja secara optimal.

8. Cake Monomer

Produk ini merupakan produk yang tidak berhasil sempurna menjadi Chip Polyester dikarenakan penghentian mesin sementara saat perawatan.

\section{Alokasi Biaya Bersama}

PT Sulindafin menggunakan metode nilai pasar dalam menghitung alokasi biaya bersama untuk produk yang dihasilkan. Diketahui bahwa nilai pasar pada bulan April adalah sebagai berikut :

\begin{tabular}{|c|c|c|c|c|}
\hline No & Nama Produk & $\begin{array}{c}\text { Jumlah } \\
\text { Produksi }\end{array}$ & Satuan & $\begin{array}{c}\text { Nilai pasar per } \\
\text { unit }\end{array}$ \\
\hline 1 & $\begin{array}{l}\text { Full Oriented } \\
\text { Yarn (FOY) }\end{array}$ & $1.812 .392,51$ & $\mathrm{Kg}$ & $9.082,23$ \\
\hline 2 & $\begin{array}{l}\text { Draw Twister } \\
\text { Yarn (DTY) }\end{array}$ & $1.396 .174,93$ & $\mathrm{Kg}$ & $8.021,45$ \\
\hline 3 & $\begin{array}{l}\text { Staple Fiber } \\
\text { (FSP) }\end{array}$ & $892.401,37$ & $\mathrm{Kg}$ & $7.007,76$ \\
\hline 4 & $\begin{array}{l}\text { Chip Polyester } \\
\text { (CP) }\end{array}$ & $333.534,20$ & $\mathrm{Kg}$ & $6.002,89$ \\
\hline
\end{tabular}

Tabel: 4.4 Harga nilai pasar bulan April 2016

Sumber: Dept. Accounting PT Sulindafin 


\begin{tabular}{|c|c|c|c|c|}
\hline 1. FOY & $=1.812 .392,51$ & $\mathrm{X}$ & $9.082,23$ & $=16.460 .565 .618,83$ \\
\hline 2. DTY & $=1.396 .174,93$ & $\mathrm{X}$ & $8.021,45$ & $=11 \cdot 199 \cdot 347.356,95$ \\
\hline 3. FSP & $892.401,37$ & $\mathrm{X}$ & $7.007,76$ & $6.253 .734 .602,21$ \\
\hline 4. $\mathrm{CP}$ & $333.534,20$ & $\mathrm{X}$ & $6.002,89$ & 1.999.317.731,48 \\
\hline & & & & $=\quad 35.912 .965 .309,48$ \\
\hline
\end{tabular}

Biaya produksi yang dikeluarkan oleh perusahaan adalah :

Biaya bahan baku

Biaya bahan pembantu

Biaya tenaga kerja langsung

Biaya Overhead pabrik (Tetap)

Biaya Overhead Pabrik (Variabel)

Total
Rp. 3.161.399.511,00

Rp. $\quad 95.580 .343,00$

Rp. 1.652.945.800,00

Rp. 1.144.876.586,00

Rp. $1.480 .423 .190,00$

Rp. 7.535.234.430,00

\section{Alokasi biaya masing-masing produk adalah :}

1. FOY $=\frac{16.460 .565 .618,83}{35.912 .965 .309,48} \times 7.535 .234 .430=3.453 .744 .900,19$

2. $\mathrm{DTY}=\frac{11.199 \cdot 347.356,95}{35.912 .965 .309,48} \times 7.535 .234 .430=2.349 .839 .593,32$

3. FSP $=\frac{6.253 .734 .602,213}{35.912 .965 .309,48} \times 7.535 .234 .430=1.312 .154 .423,47$

4. $\mathrm{CP}=\frac{1.999 .317 .731,48}{35.912 .965 .309,48} \times 7.535 .234 .430=419.495 .513,03$ Total

$$
=7.535 .234 .430,00
$$

Dari perhitungan di atas dapat terlihat alokasi biaya masing-masing produk yang dihasilkan. Untuk produk FOY biaya yang diperlukan adalah sebesar 
Rp. 3.543.114.547,44. Untuk produk DTY biaya yang diperlukan adalah sebesar Rp. 2.171.546.077,23. Untuk produk FSP biaya yang diperlukan adalah sebesar Rp. 1.368.327.454,60, serta untuk produk CP biaya yang diperlukan adalah sebesar Rp. 452.246.350,73.

Laba Rugi Segmen Atas Produk Bersama Dengan Metode Variable Costing 


\begin{tabular}{|c|c|c|c|c|c|}
\hline \multicolumn{6}{|c|}{$\begin{array}{l}\text { Laporan Laba Rugi Segmen PT Sulindafin } \\
\text { Atas Produk Bersama Metode Variable Costing } \\
\text { April } 2016\end{array}$} \\
\hline & Divisi POY & Divisi DTY & Divisi PSF & Divisi CP & Jumlah \\
\hline Penjualan bersih & $9.866 .948 .026,50$ & $8.285 .449 .118,80$ & $3.890 .837 .939,49$ & $2.125 .796 .756,39$ & $24.169 .031 .841,19$ \\
\hline $\begin{array}{l}\text { Harga pokok } \\
\text { penjualan variabel }\end{array}$ & $2.367 .514 .307,23$ & $1.095 .635 .041,66$ & $589.717 .557,58$ & $195.844 .072,51$ & 4.248.710.978,98 \\
\hline $\begin{array}{l}\text { Marjin kontribusi } \\
\text { kotor }\end{array}$ & 7.499.433.719,27 & 7.189.814.077,14 & 3.301.120.381,91 & $1.929 .952 .683,88$ & $19.920 .320 .862,21$ \\
\hline $\begin{array}{l}\text { Biaya usaha } \\
\text { variabel }\end{array}$ & $323.231 .463,68$ & $260.688 .225,23$ & $194.967 .272,54$ & $125.989 .624,55$ & $904.876 .586,00$ \\
\hline Marjin kontribusi & 7.176.202.255,59 & $6.929 .125 .851,91$ & $3.106 .153 .109,37$ & $1.803 .963 .059,33$ & $19.015 .444 .276,21$ \\
\hline $\begin{array}{l}\text { Biaya tetap yang } \\
\text { diawasi manajer } \\
\text { divisi }\end{array}$ & $35.675 .234,67$ & $30.897 .666,88$ & 12.121.312,77 & $10.987 .991,61$ & $89.682 .205,93$ \\
\hline $\begin{array}{l}\text { kontribusi } \\
\text { manajer divisi }\end{array}$ & 7.140.527.020,92 & $6.898 .228 .185,03$ & $3.094 .031 .796,60$ & $1.792 .975 .067,72$ & $18.925 .762 .070,28$ \\
\hline $\begin{array}{l}\text { Biaya tetap yang } \\
\text { diawasi manajer } \\
\text { lain }\end{array}$ & $40.119 .812,89$ & $34.989 .112,89$ & $13.956 .334,22$ & $12.012 .568,23$ & $101.077 .828,23$ \\
\hline $\begin{array}{l}\text { Kontribusi divisi- } \\
\text { divisi }\end{array}$ & 7.100.407.208,03 & $6.863 .239 .072,14$ & $3.080 .075 .462,38$ & $1.780 .962 .499,49$ & $18.824 .684 .242,05$ \\
\hline $\begin{array}{l}\text { Biaya yang tidak } \\
\text { dialokasikan }\end{array}$ & & & & & $35.312 .621,56$ \\
\hline $\begin{array}{l}\text { Penjualan produk } \\
\text { sampingan }\end{array}$ & & & & & $279.212 .559,00$ \\
\hline $\begin{array}{l}\text { Laba sebelum } \\
\text { pajak }\end{array}$ & & & & & $19.068 .584 .179,49$ \\
\hline
\end{tabular}

Dari perhitungan laba rugi segmen di atas dapat diketahui biaya masing-masing divisi pada PT Sulindafin. Untuk divisi FOY penjualan sebesar Rp 9.866.948.026,50 
memerlukan biaya tetap yang diawasi oleh manajer divisi dan manajer lain masingmasing sebesar Rp. 35.675.234,67 dan Rp. 40.119.812,89 serta menghasilkan kontribusi divisi sebesar Rp. 7.100.407.208,03. Dari angka tersebut menghasilkan perbandingan biaya tetap dengan penjualan adalah sebesar 1:130

Untuk divisi DTY penjualan sebesar Rp. 8.285.449.118,80 memerlukan biaya tetap yang diawasi oleh manajer divisi dan manajer lain masing-masing sebesar Rp. 30.897.666,88 dan Rp. 34.989.112,89 serta menghasilkan kontribusi divisi sebesar Rp. 6.863.239.072,14. Dari angka tersebut menghasilkan perbandingan biaya tetap dengan penjualan adalah sebesar 1:126

Untuk divisi PSF penjualan sebesar Rp. 3.890.837.939,49 memerlukan biaya tetap yang diawasi oleh manajer divisi dan manajer lain masing-masing sebesar Rp. 12.121.312,77 dan 13.956.334,22 serta menghasilkan kontribusi divisi sebesar Rp. 3.080.075.462,38. Dari angka tersebut menghasilkan perbandingan biaya tetap dengan penjualan adalah sebesar 1:149

Untuk divisi CP penjualan sebesar Rp. 2.125.796.756,39 memerlukan biaya tetap yang diawasi oleh manajer divisi dan manajer lain masing-masing sebesar Rp. 10.987.991,61 dan Rp. 12.012.568,23 serta menghasilkan kontribusi divisi sebesar Rp. 1.780.962.499,49. Dari angka tersebut menghasilkan perbandingan biaya tetap dengan penjualan adalah sebesar 1:92

Dari perbandingan antara biaya tetap yang dikeluarkan oleh perusahaan dengan penjualan masing-masing divisi terlihat bahwa divisi CP menghasilkan perbandingan yang lebih sedikit dari pada divisi lain. Sedangkan untuk divisi PSF memiliki perbandingan yang paling besar. Dari kesimpulan ini manajer dapat mengambil keputusan bahwa untuk mempertimbangkan kembali apakah memberhentikan produksi produk $\mathrm{CP}$ atau tetap melanjutkan produksinya dengan konsekuensi laba ke perusahaan dengan jumlah sedikit.

\section{Kesimpulan}

Berdasarkan hasil pembahasan, dapat disimpulkan bahwa : 
1. Alokasi biaya bersama pada PT Sulindafin menggunakan metode nilai pasar, yaitu metode yang membagi jumlah nilai jual masing-masing produk dengan jumlah nilai jual keseluruhan produk serta mengalikan dengan biaya bersama.

2. Perhitungan laba rugi segmen atas produk bersama pada PT Sulindafin menggunakan metode variable costing. Metode yang menghitung masing-masing produk pembebanan biaya bersama berdasarkan biaya produksi variable saja. Hasil dari perhitungan tersebut akan menjadi biaya produksi masing-masing untuk menghitung harga pokok penjualan. Unsur-unsur laporan laba rugi segmen terdiri dari penjualan bersih, harga pokok penjualan variabel produk, biaya usaha variabel, biaya tetap yang diawasi manajer divisi, biaya tetap yang diawasi manajer lain, biaya yang tidak dialokasikan dan penjualan produk sampingan.

\section{Daftar Pustaka}

Bustami,Bastian,dan Nurlela, Akuntansi Biaya, Edisi 4, Jakarta, Mitra Wacana Media, 2013

Hery, Pengantar Akuntansi:Comprehensive Edition, Jakarta, Grasindo, 2015

Kamaruddin,Ahmad, Akuntansi Manajemen:Dasar-Dasar Konsep Biaya \& Pengambilan Keputusan, Edisi 8, Jakarta, Rajawali Pers, 2013

Kusuma,Handri, et.al., Akuntansi Manajemen, Yogyakarta, Ekonisia, 2013

Putong,Iskandar, Economics: Pengantar Mikro dan Makro, Edisi 5, Jakarta, Mitra Wacana Media, 2013

Rosyidi,Suherman, Pengantar Teori Ekonomi: Pendekatan Kepada Teori Ekonomi Mikro Dan Makro, Edisi 11, Jakarta, Rajawali Pers, 2014

Salman,Riza,Kautsar,dan Farid,Mochammad, Akuntansi Manajemen:Alat Pengukuran Dan Pengambilan Keputusan Manajerial, Jakarta, Indeks, 2016 